\title{
Population-based health funding under attack
}

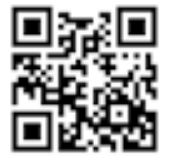

A 'static, outdated and inflexible' population-based funding formula for public health is putting huge pressure on well-run and wellequipped hospitals in the Western Cape, KwaZulu-Natal and Gauteng as people from other provinces migrate there in their tens of thousands to seek a better life.

The frustrated heads of health in these top-performing three provinces would much prefer a formula that recognises 'bang for buck' results, and for 'funding to follow functionality and service delivery'. The opposition-led Western Cape is taking legal advice on what it calls a 'constitutionally unjustified, inefficient, unfair and unacceptable' formula. The dysfunctional 'bottom three' (of nine) provincial health departments, Limpopo, Mpumalanga and the Eastern Cape, are notorious for misspending or outright misappropriating hundred million-rand chunks of their budgets annually, and the National Treasury has regularly intervened to manage their financial health. From bitter experience, many of their patients know that they are likely to get quicker and better help in neighbouring provinces.

\section{Patients go where the services are}

Meanwhile, the under-funded 'topperforming three' provincial health departments continue to render more efficient services while dealing with an everincreasing inflow of patients that fills most of their hospitals to overflowing - hostages to the national 2011 Census-based health funding formula. (A census is conducted once a decade, but National Treasury updates this annually with a mid-year population estimate by Statistics South Africa (SSA).) SSA estimates that in the five years from 2006 to 2011, some 264449 people migrated away from the Eastern Cape, while Limpopo's outward migration stood at 227 919. During the same period the Western Cape and Gauteng experienced a net inflow of migrants of 307411 and 1046 641, respectively. No geography prizes for working out that the former came mostly from the Eastern Cape and the latter mainly from Limpopo and Mpumalanga.

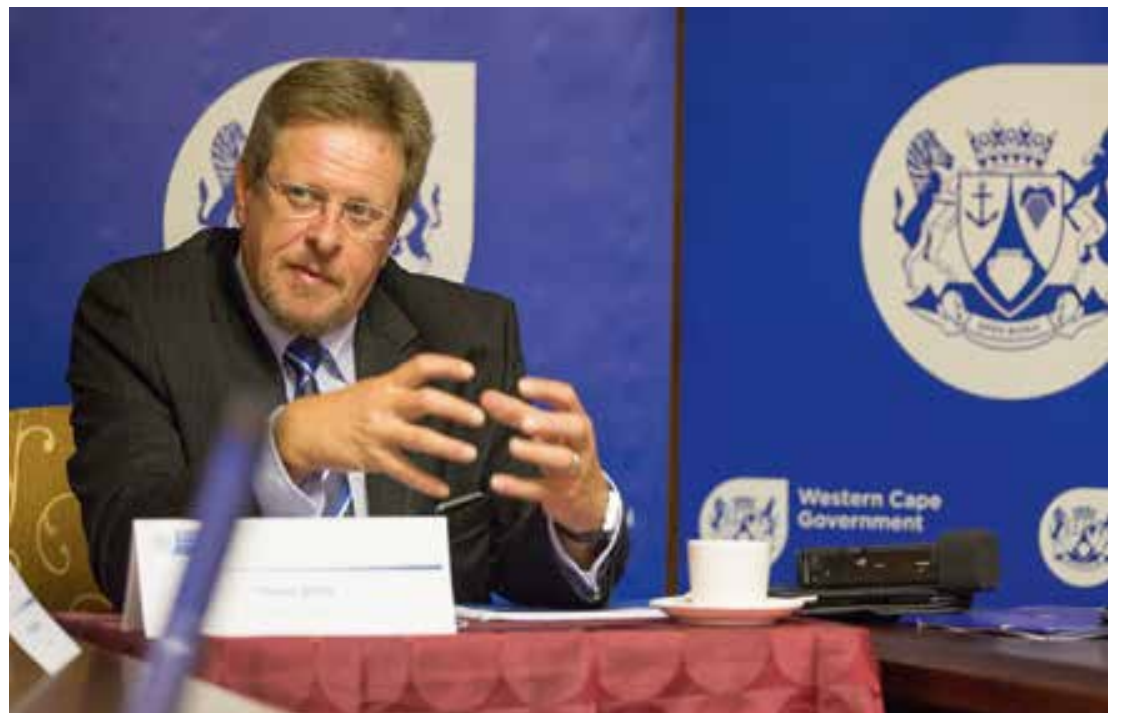

Western Cape Health MEC, Theuns Botha. Picture: Chris Bateman.

Western Cape Health MEC Theuns Botha says that an analysis of service pressures at health facilities across his province shows a $28 \%$ population increase - which he's prepared to service, freedom of movement being a constitutional right - but that the national government has a 'commensurate and constitutional obligation' to compensate provinces for services rendered. 'The more we improve our services, the more patients we attract, he adds, citing the irony of having seen few visible results in spite of several 'ground-breaking initiatives' to reduce waiting times. All Cape Metro acute hospitals were well above the minimum optimal efficiency occupation level of $85 \%$, with the largest and busiest referral hospital, Tygerberg, $87 \%$ full, meaning that corridor beds, trolleys in wards and ambulance diversions were the norm. The busiest hospital, the newly commissioned Khayelitsha District Hospital, was 131\% full, followed by Westfleur Hospital (107\%), Eerste River Hospital (103\%), Helderberg Hospital (101\%) and Victoria Hospital (99\%). The average projected patient occupancy rate for all 13 Cape Metro hospitals for $2013 / 2014$ was $91 \%$. In spite of a large district hospital being built in Khayelitsha, the Peninsula's most populous township, calculations showed that the unmet patient need there now stood at $1000-1300$ additional admissions per year.

\section{W Cape hospitals}

\section{bursting at the seams}

Botha said that Tygerberg Hospital saw 20\% of the province's annual patient load of 80000 and required R267 million per year to run and maintain. However, the province could only afford to allocate R83 million, meaning that the hospital ran on a R192 million annual shortfall. He emphasised that seeking legal advice on the constitutionality of the current Devolution of Revenue Act was not a threat. 'We need to get the arguments and legal issues sorted out to promote our opinion and change the budget allocation formula. It may require a change in legislation - it will definitely require policy deviation. Perhaps as importantly, there is simply no way a National Health Insurance scheme will fly without this budgetary reform. They used to talk about unfunded mandates - well, this falls within that category', Botha added. His examples of 'ground-breaking' Western Cape healthcare innovations include decentralised deliveries of prescription medication to nonprimary healthcare sites for collection (with SMS notification), which should lead to a reduction of $30 \%$ in the patient load at clinics and day hospitals. So far 50000 primary healthcare patients are said to be benefiting from this system, which puts medicines closer to their homes, with a targeted patient base of 150000 . Over 100 new healthcare facilities have opened over the 
past four and a half years, while a cell-phonebased patient complaints mechanism means that any complaint is dealt with inside two hours, vastly improving healthcare worker accountability and service quality monitoring. An increasingly efficient patient transport system helps deliver 3500 rural patients to Cape Metro hospitals monthly, using a widely advertised booking system, while local authorities have helped erect new allweather shelters at specific pick-up points across the province. Botha said a multilateral service agreement between the provincial health department and the four universities that provide expert clinical services meant avoiding the debilitating disputes that made headlines in the Free State, Gauteng and Eastern Cape academic health complexes last year. An ambitious 'wellness' programme was now firmly entrenched, as was a private sector foundation aimed at generating further income through innovative public/ private ventures.

\section{Relentless patient pressure blunts most initiatives - Botha}

However, the relentless growth in patient pressure has blunted many initiatives. At Tygerberg Hospital, in spite of 30 theatres being operational daily, long waiting lists for emergency as well as surgical procedures remain. Patients with open fractures wait for up to 72 hours, while waiting times for elective procedures like removal of an enlarged prostate now stretch to a year. Spinal surgery candidates generally wait 48 weeks, and cancer surgery waits stand at between 6 and 16 weeks (there were 280 patients in three cancer groups waiting at the time of writing). Patients requiring knee and hip replacements can wait eight years. Botha said that R6 billion had been set aside to expand and revamp the hospital. Tygerberg Hospital's three main feeder hospitals had increased maternity referrals by 100 deliveries per month between January 2011 and January 2014 - with 46\% of these women requiring caesarean sections, indicating the complexity and urgency of the cases. Over $30 \%$ of babies were of low birth weight, requiring further inpatient care. The overall patient-day-equivalent load on Tygerberg had increased by $18 \%$. Just under a third (30\%) of all patients requiring dialysis managed to get onto the programme, while there had been a $69 \%$ increase in patients needing emergency medical services.

Izindaba sources in National Treasury defended the funding formula, claiming that money went 'where people get services', but conceded that responding to migratory patterns was a challenge. There are three main sources of healthcare funding, the largest the equitable grant, followed by the national tertiary services grant, plus the infrastructure health facility revitalisation grant. The overall funding formula is based on each province's disease burden, its uninsured population and adjusted census data - with actual use of hospitals and clinics measured and factored in. For the first time in the 2013/2014 national budget process, performance-based measurements were used in the health facility revitalisation grant - but the impact is obviously yet to be felt.

One national treasury source said that any cost-pressured head of department would like more money, but 'the other side of the story' lay in the views of the less-resourced provinces, which faced 'very real pressures'. 'You can't ignore these people and those who depend on their services, but clearly performance needs to be improved,' he added.

\section{Chris Bateman}

chrisb@hmpg.co.za

S Afr Med J 2014;104(5):329-330.

DOI:10.7196/SAMJ.8172 